\title{
Diets of walleye pollock Theragra chalcogramma in the Doto area, northern Japan: ontogenetic and seasonal variations
}

\author{
Orio Yamamura ${ }^{1, *}$, Satoshi Honda ${ }^{1}$, Osamu Shida ${ }^{2}$, Tomonori Hamatsu ${ }^{1}$ \\ ${ }^{1}$ Hokkaido National Fisheries Research Institute, 116 Katsurakoi, Kushiro 085-0802, Japan \\ ${ }^{2}$ Muroran Branch, Hakodate Fisheries Experiment Station, 1-133 Funami-cho, Muroran 051-0013, Japan
}

\begin{abstract}
Seasonal, ontogenetic and bathymetric variations of diet were examined for walleye pollock Theragra chalcogramma based on a total of 6666 fish collected off the southeastern coast of Hokkaido Island, northern Japan (Doto area) during 1989 to 2000. Walleye pollock depended exclusively (>99\%) on pelagic prey and showed a clear ontogenetic dietary shift: smaller fish depended mainly upon mesozooplankton such as Neocalanus cristatus and Euphausia pacifica, and larger fish preyed upon pollock (cannibalism), myctophids Diaphus theta and firefly squid Watasenia scintillans. Seasonal variation was also evident. Smaller pollock depended mainly upon N. cristatus during spring then shifted gradually to E. pacifica during other seasons. For larger pollock, major prey shifted from pollock (cannibalism) during spring to micronekton during other seasons. Bathymetric variation was less pronounced, with cannibalism and Themisto spp. being more important in the shallow area $(\leq 150 \mathrm{~m})$. Feeding intensity, measured as stomach content index, was generally higher during spring and summer than autumn and winter, but showed incidentally high values during winter, suggesting sporadic but intense feeding opportunities. Fish condition fell during winter and then recovered rapidly during May and June. Recovery coincided with superabundance of $N$. cristatus during blooming, so that this species is essential for the recovery of pollock from wintering and spawning.
\end{abstract}

KEY WORDS: Theragra chalcogramma $\cdot$ Food habits $\cdot$ Seasonality $\cdot$ Feeding intensity $\cdot$ Condition

\section{INTRODUCTION}

The nutrition of high latitude fishes varies seasonally. These fishes generally feed during the productive spring and summer in order to endure (and compensate for) the less productive winter. This cycle reflects seasonal variation of the physical environment and resulting prey availability (MacKinnon 1972, Dygert 1990, Robards et al. 1999). Prey for various fishes exhibit an intense decline during winter resulting in occasional starvation mortality of the fishes (Adams et al. 1982, Henderson et al. 1988). Fish diets also vary ontogenetically due to changes in gape morphology,

*E-mail: orioy@affrc.go.jp swimming ability, feeding tactics and distribution (e.g. Eggold \& Motta 1992). Maximum prey size increases with fish growth whereas minimum prey size increases only slightly with fish growth. This results in an 'asymmetric predator-prey size distribution' (Scharf et al. 2000). Such variation would facilitate ontogenetically different responses in a spectrum of available prey and further determine the pattern of resource use in a community (Hyndes et al. 1997).

Walleye pollock Theragra chalcogramma is a key species of the subarctic North Pacific, which is distributed from the coast of Korea through the northwestern coast of the USA (Bailey et al. 1999). Besides being an important prey for demersal fishes, marine mammals and seabirds (Springer 1992, Livingston 1993, Mito et al. 1999), it also supports the largest single-species 
fisheries in the world (Anonymous 2000). Due to their predominance, pollock has the potential to impact entire ecosystems (Springer 1992). Although numerous studies have been made on the feeding habits of postsettlement pollock (Takahashi \& Yamaguchi 1972, Bailey \& Dunn 1979, Clausen 1983, Maeda 1986, Dwyer et al. 1987, Grover 1991, Yoshida 1994, Merati \& Brodeur 1996, 1998, Kooka et al. 1997), most of them covered only limited seasons and fish sizes. The studies made by Dwyer et al. (1987) and Mito et al. (1999) in the Bering Sea were exceptionally comprehensive describing geographical, seasonal and ontogenetic variations of pollock diet. They revealed that pollock depends primarily upon pelagic prey and shift gradually from zooplankton to fishes during growth. However, they identified the prey only to the major taxonomic levels.

The southeastern coast of Hokkaido Island, northern Japan (Doto area, Fig. 1) is the major feeding ground of the Japan Pacific population of walleye pollock (JPP). The spawning of JPP occurs mainly during January and February in the area of Funka Bay (Maeda 1986). As age-0 pollock grow to $85 \mathrm{~mm}$ in total length, a substantial part of age-0 pollock settle during late summer and early autumn in the Doto area (Miyake et al. 1996), where they winter and reside for years. Although cross- and along-shore migrations of the Doto pollock have been observed regularly even to the southern Kuril Islands and northeastern coast of the main island of Japan, their residence in the Doto area is considered to be stable based on the results of tagging experiments and hydroacoustic surveys (Maeda 1986, S. Honda unpubl. data). The Doto area is strongly influenced by the Oyashio current, which causes conspicuous seasonal and interannual variabilities in physical and biological environments (Kono \& Kawasaki 1997, Saito et al. 1998, Mackas \& Tsuda 1999). These vari-

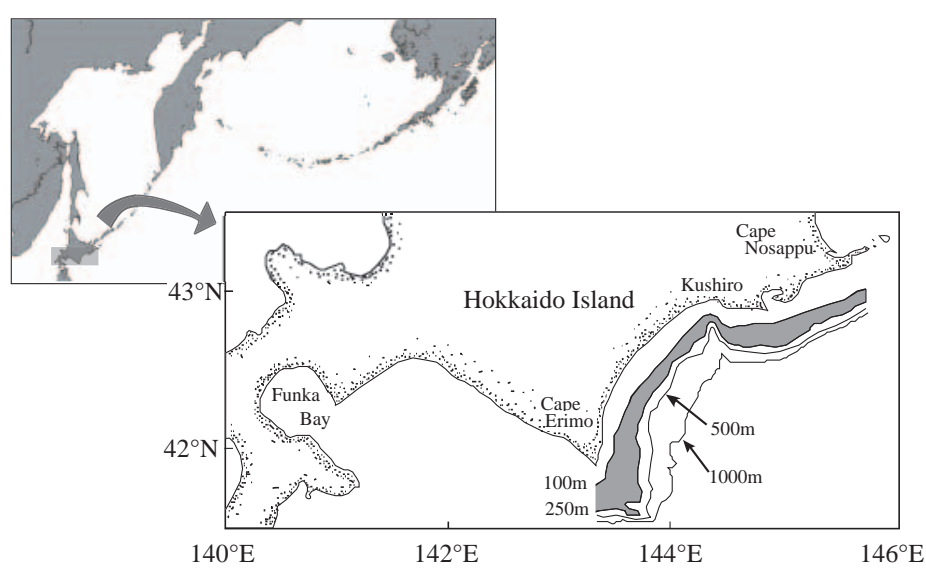

Fig. 1. Map showing the area studied relative to the North Pacific (inset) and the area of sample collection (shaded area). Some fish samples were collected outside of the depth range abilities clearly affect food habits and the resulting condition of pollock, as has been observed in other areas (Smith et al. 1988, Paul et al. 1998, Willette et al. 1999), and further results in variations in winter survival of juveniles and reproductive potential of spawning adults (Harris et al. 1986, Sogard 1997, Marshall et al. 1999). In the present study, we examined seasonal and ontogenetic variations of diets and feeding condition of pollock collected in the Doto area over $10 \mathrm{yr}$ as well as clarifying the key prey determining the condition of pollock.

\section{MATERIALS AND METHODS}

Fish specimens included in the present study were sampled in the Doto area bounded by Capes Erimo and Nosappu and the isobathes of 100 to $250 \mathrm{~m}$ (Fig. 1). Although the depths sampled ranged from 41 to $540 \mathrm{~m}$, the greatest portion $(72.8 \%)$ of specimens was collected from 100 to $250 \mathrm{~m}$. The samples were obtained from 1989 to 1992 and from 1995 to 2000. Fish were sampled mainly by bottom $(\mathrm{N}=3160)$ and midwater $(\mathrm{N}=2297)$ trawling and hook-and-line fishing $(\mathrm{N}=70)$ operated by research vessels, while some were caught by commercial bottom trawling $(\mathrm{N}=710)$ and gillnet $(\mathrm{N}=429)$. The number of fish specimens were classified by year, month, depth of capture and fish size (Table 1). The time of commercial fishing operations was unavailable although it occurred mostly during daytime. Fish were measured and weighed to the nearest $1 \mathrm{~mm}$ standard length (SL) and $5 \mathrm{~g}$, respectively, on board or in the laboratory, after which they were dissected and their stomachs fixed in a $10 \%$ formalin-seawater solution. In the laboratory, stomachs were cut open and food items were sorted to the lowest possible taxon. When unnaturally intact prey such as fish with complete scales was found, they were regarded as ingested in the net and excluded from the analysis. Each prey item was dried at $52^{\circ} \mathrm{C}$ in a drying oven for $24 \mathrm{~h}$ and in a desiccator for 36 to $48 \mathrm{~h}$, and then weighed to the nearest $1 \mathrm{mg}$. The data are divided according to predator $10 \mathrm{~cm}$ size class and season (Spring, April to June; Summer, July to September, etc.). Diets were also analyzed by depth stratum (shallow, $\leq 150 \mathrm{~m}$; deep, >150 $\mathrm{m}$ in bottom depths).

To examine the seasonal variation of feeding intensity, stomach content index (SCI) was calculated as follows:

$$
\mathrm{SCI}=(\mathrm{SCW} / \mathrm{BW}) \times 10^{3}
$$

where SCW is dry weight $(\mathrm{g})$ of stomach contents and BW is body weight. SCI was averaged for each $10 \mathrm{~cm}$ size class and month. Subsamples representing $\geq 30$ fish specimens were included. Fish condition was cal- 
Table 1. Theragra chalcogramma. Number of specimens, the stomachs of which were examined in this study

\begin{tabular}{|c|c|c|c|c|c|c|c|c|c|}
\hline & \multicolumn{4}{|c|}{ Shallow waters $(<150 \mathrm{~m})$} & \multicolumn{4}{|c|}{ Deep waters (>150 m) } & \multirow[b]{2}{*}{ Total } \\
\hline & $<200$ & $201-300$ & $301-400$ & $>400$ & $<200$ & $201-300$ & $301-400$ & $>400$ & \\
\hline Spring (Apr - Jun) & 273 & 159 & 211 & 87 & 133 & 97 & 444 & 247 & 1651 \\
\hline Summer (Jul - Sep) & 284 & 6 & 0 & 0 & 95 & 173 & 237 & 151 & 946 \\
\hline Autumn (Oct - Dec) & 292 & 187 & 134 & 36 & 391 & 557 & 279 & 142 & 2018 \\
\hline Winter (Jan - Mar) & 114 & 157 & 100 & 64 & 144 & 423 & 491 & 558 & 2051 \\
\hline Total & 963 & 509 & 445 & 187 & 763 & 1250 & 1451 & 1098 & 6666 \\
\hline
\end{tabular}

culated to examine the seasonal variation of nutritional accumulation. Although BW of pollock specimens for stomach contents analysis was measured, no measurement was available for gonads. Therefore, it was inevitably affected by hydration of gonad during maturation, and the nourishment would be biased toward overestimate during autumn and winter if BW was used for examining fish condition. We therefore calculated the following condition factor index (CF) based on a total of 24771 market-size specimens collected during 1984 to 1997 :

$$
\mathrm{CF}=[(\mathrm{GutW}+\mathrm{LW}) / \mathrm{SL}] \times 10^{6}
$$

where GutW is gutted weight $(g)$ and LW is liver weight. LW was included since absorbed energy is initially stored in the liver as somatic tissue energy in pollock (Maeda 1986, Smith et al. 1988). Few specimens $\leq 200 \mathrm{~mm}$ SL had been available in the market, so the sample was divided into 'large' (>400 mm) and 'small' $(\leq 400 \mathrm{~mm})$ size classes, and the index was calculated for the each month. The importance of various food taxa was represented in terms of dry weight composition and frequency of occurrence. The diet was compared between different predator size classes, seasons, depth strata and fishing gears. In the comparison for fishing gear, specimens were divided into 'midwater' (collected by midwater trawling) and 'bottom' (collected by bottom trawling and bottom gillnet) samples.

\section{RESULTS}

\section{Overall diet}

The body size of 6666 fish examined for stomach contents ranged from 68 to $681 \mathrm{~mm}$ SL. Of these, 899 $(13.5 \%)$ had empty stomachs. The diet of walleye pollock varied widely with fish size, and was predominated by pelagic organisms such as zooplankton, mesopelagic and pelagic fishes, whereas benthic animals represented $<1 \%$ in all of the size classes (Table 2). The prey items varied widely, representing over 80 taxa, but several major categories such as copepods, amphipods, euphausiids, decapod cephalo- pods and osteichthys made up the bulk of the diet (>96\% in all size classes). Of the 6 species of decapod cephalopods identified, firefly squid Watasenia scintillans was most important, making up $20.1 \%$ in DW composition of the 201 to $300 \mathrm{~mm}$ size class. Most of the other squids identified were gonatiids, but a benthic sepiorid Rossia pacifica was found in a $621 \mathrm{~mm}$ SL pollock. Larger species such as Berryteuthis magister and Japanese common squid Todarodes pacificus were also identified, but they were not found as whole bodies, but as fragments of posterior (head and tentacles) or anterior (fin) parts. This suggests scavenging by pollock on leftovers discarded by predatory (or cannibalistic) squids, as reported for brown hakeling Physiculus maximowiczi by Kitagawa et al. (1992). The importance of copepods was higher in smaller pollock, constituting $42.4 \%$ of $\leq 200 \mathrm{~mm}$ fish diet. Neocalanus cristatus was predominant representing $>83 \%$ of the copepods identified in each size class. Other species such as Neocalanus plumchrus/flemingeri and Eucalanus bungii represented $<1 \%$. Euphausiids were the most important prey for $\leq 400 \mathrm{~mm}$ size classes; of the 7 species identified, Euphausia pacifica was most important representing 76.1 to $90.0 \%$ of identifiable euphausiids. Other commonly occurring euphausiids were Thysanoessa inermis and T. longipes. Hyperiids, represented mainly by Themisto sp. were less important compared with copepods and euphausiids constituting $4.7 \%$ of the diet of $>400 \mathrm{~mm}$ fish. At least 10 species of decapod crustaceans, including natant and carid shrimps and hermit crabs, were identified; however, they were of limited importance $(<1.2 \%)$. A total of 27 fish taxa were identified and became more diverse and important in pollock of larger size. Most of the fish identified were mesopelagic species such as bathylagids, gonostomatids, myctophids and macrourids. Of these, myctophids were predominant with Diaphus theta being the most common. Walleye pollock (i.e. cannibalism) was an important prey item for the largest size class accounting for $23.9 \%$ of total diet. As presented in Yamamura et al. (2001), most of the cannibalized prey were age-1 pollock. The epipelagic fishes Japanese anchovy Engraulis japonicus and saury Cololabis saira were less important. 
Table 2. Theragra chalcogramma. Dry weight percent composition (W) and percent frequency of occurrence (F) of prey items in the diet of different size classes. F was calculated based on the number of stomachs containing food: $+:<0.01 \%$; ${ }^{a}$ benthic organisms: ${ }^{\mathrm{b}}$; mesopelagic fish

\begin{tabular}{|c|c|c|c|c|c|c|c|c|}
\hline \multirow{2}{*}{ Size class (mm) } & \multicolumn{2}{|c|}{$\leq 200 \mathrm{~mm}$} & \multicolumn{2}{|c|}{$201-300 \mathrm{~mm}$} & \multicolumn{2}{|c|}{$301-400 \mathrm{~mm}$} & \multicolumn{2}{|c|}{$>400 \mathrm{~mm}$} \\
\hline & $\mathrm{W}$ & $\mathrm{F}$ & W & $\mathrm{F}$ & $\mathrm{W}$ & $\mathrm{F}$ & $\mathrm{W}$ & $\mathrm{F}$ \\
\hline Protozoa: Radiolaria & + & 0.06 & - & - & - & - & + & 0.08 \\
\hline Ctenophora & - & - & + & 0.11 & + & + & + & 0.16 \\
\hline Annelida: Polychaeta & 0.04 & 0.34 & 0.06 & 1.20 & 0.05 & 0.05 & 0.03 & 1.09 \\
\hline Chaetognatha: Sagitta sp. & 0.50 & 4.46 & 0.22 & 4.12 & 0.52 & 0.52 & 0.20 & 4.28 \\
\hline \multicolumn{9}{|l|}{ Mollusca } \\
\hline Buccinidae & - & - & + & 0.06 & - & - & 0.01 & 0.08 \\
\hline Limacinidae & 0.02 & 0.17 & 0.01 & 0.23 & 0.02 & 0.02 & 0.07 & 0.39 \\
\hline \multicolumn{9}{|l|}{ Decapod Cephalopoda } \\
\hline Unidentified & - & - & 0.10 & 0.34 & 0.08 & 0.08 & 0.17 & 2.02 \\
\hline Rossia pacifica ${ }^{a}$ & - & - & - & - & - & - & 0.03 & 0.08 \\
\hline Watasenia scintillans & 1.22 & 0.17 & 20.10 & 3.89 & 13.95 & 14.06 & 1.47 & 1.40 \\
\hline Gonatidae (unid.) & - & - & - & - & 0.04 & 0.04 & 0.23 & 1.25 \\
\hline Berryteuthis magister & - & - & - & - & - & - & 0.51 & 0.08 \\
\hline Gonatus onyx & - & - & + & 0.06 & 0.17 & 0.17 & 0.26 & 0.86 \\
\hline Gonatopsis makko & - & - & - & - & 0.99 & 1.00 & - & - \\
\hline Gonatopsis sp. & - & - & - & - & - & - & 0.26 & 0.23 \\
\hline Todarodes pacificus & - & - & - & - & 0.07 & 0.07 & 0.04 & 0.08 \\
\hline \multicolumn{9}{|l|}{ Arthropoda } \\
\hline Ostracoda & + & 0.06 & + & 0.06 & - & - & - & - \\
\hline \multicolumn{9}{|l|}{ Copepoda } \\
\hline Unidentified & 31.31 & 31.79 & 6.47 & 11.45 & 2.57 & 2.51 & 1.32 & 4.98 \\
\hline Neocalanus cristatus & 9.24 & 5.77 & 5.10 & 4.81 & 9.92 & 9.99 & 2.62 & 10.66 \\
\hline N. plumchrus / flemingeri & 0.89 & 1.89 & - & - & + & + & - & - \\
\hline Eucalanus bungii & 0.63 & 2.46 & 0.09 & 1.26 & 0.06 & 0.06 & 0.00 & 0.08 \\
\hline Metridia sp. & 0.32 & 0.29 & + & 0.11 & - & - & - & - \\
\hline Euchaeta sp. & 0.03 & 0.91 & + & 0.74 & 0.01 & 0.01 & 0.05 & 1.95 \\
\hline Candacia sp. & + & 0.34 & 0.01 & 2.23 & + & + & + & 1.63 \\
\hline Total Copepoda & 42.42 & & 11.68 & & 12.57 & & 4.00 & \\
\hline Mysidacea (unid.) & + & 0.06 & + & 0.06 & 0.05 & 0.05 & 0.11 & 1.09 \\
\hline Meterithrops microphthalma & + & 0.11 & 0.09 & 0.34 & 0.11 & 0.11 & 0.17 & 1.95 \\
\hline Neomysis sp. & 0.16 & 3.54 & + & 0.06 & - & - & - & - \\
\hline Ianiridea & + & 0.06 & - & - & - & - & - & - \\
\hline Gammaridea (total) & 0.28 & & & 0.12 & 0.23 & & 0.21 & \\
\hline Unidentified & 0.03 & 1.03 & 0.07 & 1.20 & 0.04 & 0.04 & + & 0.54 \\
\hline Ampelisca sp. & 0.24 & 1.60 & 0.04 & 0.52 & 0.19 & 0.19 & 0.13 & 2.02 \\
\hline Bibris sp. & + & 0.34 & - & - & + & + & + & 0.08 \\
\hline Anonyx sp. & + & 0.06 & + & 0.11 & + & + & 0.07 & 0.47 \\
\hline Cyphocaris challengeri & - & - & + & 0.40 & + & + & + & 0.23 \\
\hline \multicolumn{9}{|l|}{ Hyperiidea } \\
\hline Unidentified & 0.03 & 0.23 & + & 0.06 & 0.01 & 0.01 & + & 0.16 \\
\hline Themisto japonica/pacifica & 1.19 & 10.12 & 1.41 & 18.79 & 1.74 & 1.75 & 4.74 & 29.88 \\
\hline Primno sp. & - & - & + & 0.06 & + & + & + & 0.47 \\
\hline Phronima sp. & - & - & - & - & - & - & + & 0.08 \\
\hline Phronima atlantica & - & - & - & - & - & - & + & 0.08 \\
\hline Vibilia sp. & + & 0.06 & - & - & + & + & + & 0.16 \\
\hline Total Hyperiidea & 1.22 & & 1.42 & 1.75 & & 4.75 & & \\
\hline \multicolumn{9}{|l|}{ Euphausiacea } \\
\hline Unidentified & 6.33 & 9.49 & 1.87 & 8.48 & 3.38 & 3.37 & 4.64 & 12.76 \\
\hline Euphausia pacifica & 40.47 & 49.34 & 34.46 & 63.34 & 24.15 & 24.26 & 13.25 & 46.23 \\
\hline E. pacifica (juvenile/furcilia) & 0.32 & 4.63 & 0.60 & 4.52 & 0.09 & 0.09 & 0.12 & 0.78 \\
\hline Thysanoessa sp. & - & - & - & - & 0.10 & 0.10 & 0.08 & 0.23 \\
\hline Th. inermis & 2.83 & 2.46 & 1.63 & 4.24 & 1.25 & 1.25 & 0.97 & 6.93 \\
\hline Th. longipes & 1.12 & 1.33 & 2.82 & 2.84 & 3.50 & 3.52 & 2.87 & 8.64 \\
\hline Th. macrura & - & - & - & - & 0.01 & 0.01 & + & 0.08 \\
\hline Th. rashi & - & - & 0.01 & 0.06 & 0.02 & 0.02 & 0.11 & 0.16 \\
\hline Th. spinifera & - & - & + & 0.06 & + & + & - & - \\
\hline Tessarabrachion oculatum & 0.22 & 0.69 & 0.28 & 2.52 & 0.08 & 0.08 & 0.01 & 0.62 \\
\hline Total Euphausiacea & 51.29 & & 41.68 & & 32.58 & & 22.04 & \\
\hline
\end{tabular}


Table 2 (continued)

\begin{tabular}{|c|c|c|c|c|c|c|c|c|}
\hline \multirow[t]{2}{*}{ Size class (mm) } & \multicolumn{2}{|c|}{$\leq 200 \mathrm{~mm}$} & \multicolumn{2}{|c|}{$201-300 \mathrm{~mm}$} & \multicolumn{2}{|c|}{$301-400 \mathrm{~mm}$} & \multicolumn{2}{|c|}{$>400 \mathrm{~mm}$} \\
\hline & $\mathrm{W}$ & $\mathrm{F}$ & W & $\mathrm{F}$ & $\mathrm{W}$ & $\mathrm{F}$ & $\mathrm{W}$ & $\mathrm{F}$ \\
\hline \multicolumn{9}{|l|}{ Decapod Crustacea } \\
\hline Unidentified & 0.02 & 0.11 & + & 0.06 & - & - & + & 0.23 \\
\hline Unidentified zoea & + & 0.29 & - & - & - & - & - & - \\
\hline Acanthephyra sp. & - & - & - & - & - & - & 0.01 & 0.08 \\
\hline Bentheogennema borealis & - & - & - & - & + & + & 0.01 & 0.16 \\
\hline Sergestes similis & 0.14 & 0.06 & 0.15 & 0.69 & 0.83 & 0.84 & 0.11 & 1.71 \\
\hline Hippolytidae sp. & 0.03 & 0.06 & - & - & - & - & 0.01 & 0.16 \\
\hline Pandalus borealis ${ }^{\mathrm{a}}$ & - & - & - & - & 0.02 & 0.02 & - & - \\
\hline Crangonidae (unid.) ${ }^{\mathrm{a}}$ & 0.04 & 0.74 & 0.01 & 0.11 & + & + & + & 0.08 \\
\hline Neocrangon sp. ${ }^{\mathrm{a}}$ & 0.15 & 0.11 & - & - & - & - & - & - \\
\hline Neocrangon communis ${ }^{\mathrm{a}}$ & 0.30 & 0.23 & 0.36 & 0.92 & 0.18 & 0.18 & 0.61 & 3.19 \\
\hline Argis sp. ${ }^{\mathrm{a}}$ & - & - & - & - & 0.02 & 0.02 & - & - \\
\hline A. $\operatorname{lar}^{\mathrm{a}}$ & - & - & - & - & 0.09 & 0.09 & 0.06 & 0.31 \\
\hline Paguridea (unid.) ${ }^{\mathrm{a}}$ & - & - & + & 0.11 & - & - & - & - \\
\hline Pagurus trigonocheirus ${ }^{\mathrm{a}}$ & 0.04 & 0.06 & - & - & 0.02 & 0.02 & - & - \\
\hline Brachyura (megalopae) & + & 0.11 & + & 0.11 & - & - & - & - \\
\hline Total decapod Crustacea & 0.73 & & 0.53 & & 1.16 & & 0.82 & \\
\hline Cumacea & 0.22 & 2.52 & 0.02 & 1.78 & + & + & + & 0.08 \\
\hline Echinodermata: Ophiuroidea ${ }^{a}$ & - & - & - & - & + & + & + & 0.08 \\
\hline Protochordata: Oikopleura sp. & 1.69 & 3.83 & 1.53 & 3.44 & 0.76 & 0.77 & 0.98 & 2.65 \\
\hline \multicolumn{9}{|l|}{ Vertebrata } \\
\hline \multicolumn{9}{|l|}{ Osteichthys } \\
\hline Unidentified & - & - & 0.62 & 1.20 & 2.15 & 2.17 & 1.41 & 4.28 \\
\hline Unidentified larvae & - & - & - & - & + & + & - & - \\
\hline Engraulis japonicus & - & - & 0.01 & 0.06 & 2.78 & 2.76 & 3.94 & 0.93 \\
\hline Bathylagidae sp. ${ }^{\mathrm{b}}$ & - & - & 0.15 & 0.06 & - & - & 0.01 & 0.16 \\
\hline Leuroglossus schmidti ${ }^{\mathrm{b}}$ & 0.01 & 0.11 & 0.10 & 0.23 & 0.88 & 0.89 & 0.81 & 2.02 \\
\hline L. schmidti (larvae) ${ }^{\mathrm{b}}$ & 0.02 & 0.17 & - & - & + & + & + & 0.16 \\
\hline Bathylagus sp. ${ }^{\mathrm{b}}$ & - & - & - & - & - & - & 0.41 & 0.23 \\
\hline B. ochotensis ${ }^{\mathrm{b}}$ & - & - & 0.24 & 0.06 & 0.08 & 0.08 & 0.32 & 0.39 \\
\hline B. milleri ${ }^{\mathrm{b}}$ & - & - & - & - & - & - & 0.20 & 0.08 \\
\hline B. pacificus ${ }^{\mathrm{b}}$ & - & - & - & - & - & - & 0.14 & 0.16 \\
\hline Maurolicus muelleri ${ }^{\mathrm{b}}$ & - & - & + & 0.06 & - & - & - & - \\
\hline Gonostoma gracile & - & - & - & - & 0.22 & 0.22 & 0.09 & 0.23 \\
\hline Cyclothone alba $\mathrm{b}^{\mathrm{b}}$ & - & - & + & 0.11 & + & + & + & 0.23 \\
\hline Vinciguerria nimbaria $^{\mathrm{b}}$ & - & - & - & - & - & - & 0.03 & 0.16 \\
\hline Chauliodus sp. ${ }^{\mathrm{b}}$ & - & - & - & - & - & - & 0.03 & 0.08 \\
\hline Tactostoma macropus ${ }^{\mathrm{b}}$ & - & - & - & - & + & + & - & - \\
\hline Myctophidae (total) & - & & 17.81 & & 19.87 & 1 & 29.46 & \\
\hline Myctophidae sp. ${ }^{\text {b }}$ & - & - & 3.15 & 0.86 & 6.46 & 6.51 & 13.10 & 5.60 \\
\hline Lampanyctus sp. ${ }^{\mathrm{b}}$ & - & - & - & - & + & + & - & - \\
\hline L. jordani ${ }^{\mathrm{b}}$ & - & - & - & - & 0.77 & 0.77 & 3.11 & 0.78 \\
\hline L. regalis ${ }^{\mathrm{b}}$ & - & - & - & - & 0.19 & 0.19 & 3.74 & 0.70 \\
\hline Diaphus sp. ${ }^{\mathrm{b}}$ & - & - & 0.33 & 0.11 & 0.05 & 0.05 & 0.05 & 0.08 \\
\hline D. theta ${ }^{\mathrm{b}}$ & - & - & 13.32 & 2.29 & 10.91 & 10.99 & 7.17 & 3.42 \\
\hline Myctophum sp. ${ }^{\mathrm{b}}$ & - & - & - & - & 0.92 & 0.93 & 0.03 & 0.08 \\
\hline M. asperum ${ }^{\mathrm{b}}$ & - & - & 0.25 & 0.06 & 0.19 & 0.19 & - & - \\
\hline Tarletonbeania taylori $^{\mathrm{b}}$ & - & - & - & - & + & + & + & 0.08 \\
\hline Protomyctophum thompsoni ${ }^{\mathrm{b}}$ & - & - & + & 0.17 & - & - & 0.15 & 0.08 \\
\hline Stenobrachius leucopsarus ${ }^{\mathrm{b}}$ & - & - & - & - & 0.01 & 0.01 & 0.10 & 0.23 \\
\hline Symbolophorus californiensis ${ }^{\mathrm{b}}$ & - & - & - & - & 0.21 & 0.21 & 2.01 & 0.47 \\
\hline Ceratoscoperus warmingi ${ }^{\mathrm{b}}$ & - & - & 0.76 & 0.11 & 0.15 & 0.15 & - & - \\
\hline Paralepidiidae sp. ${ }^{\text {b }}$ & - & - & - & - & - & - & 0.58 & 0.23 \\
\hline Benthalbella sp. (larvae) ${ }^{\mathrm{b}}$ & - & - & - & - & + & + & 0.61 & 0.08 \\
\hline Theragra chalcogramma & - & - & 3.15 & 0.52 & 8.31 & 8.37 & 23.88 & 5.29 \\
\hline Macrouridae sp. ${ }^{b}$ & - & - & - & - & 0.04 & 0.04 & - & - \\
\hline Lumpenus sagitta $^{\mathrm{a}}$ & - & - & - & - & - & - & 0.11 & 0.08 \\
\hline Cololabis saira & - & - & $-\quad-$ & - & - & 1.33 & 0.31 & \\
\hline Total fish & 0.04 & & 21.98 & & 34.24 & & 63.37 & \\
\hline Unidentified gelatinous matter & 0.02 & 0.06 & 0.02 & 0.34 & + & + & 0.02 & 0.78 \\
\hline Unidentified digested matter & 0.14 & 0.86 & 0.32 & 2.41 & 0.53 & 0.53 & 0.25 & 2.26 \\
\hline No. of stomachs examined & \multicolumn{2}{|c|}{1726} & \multicolumn{2}{|c|}{1746} & \multicolumn{2}{|c|}{1884} & \multicolumn{2}{|c|}{1285} \\
\hline No. of stomachs containing food & 1427 & $2.7 \%)$ & 1509 & $6.4 \%)$ & 1731 & $1.9 \%)$ & 1076 & $3.7 \%)$ \\
\hline Total DW of food examined & & & 36 & & 161 & & & \\
\hline
\end{tabular}




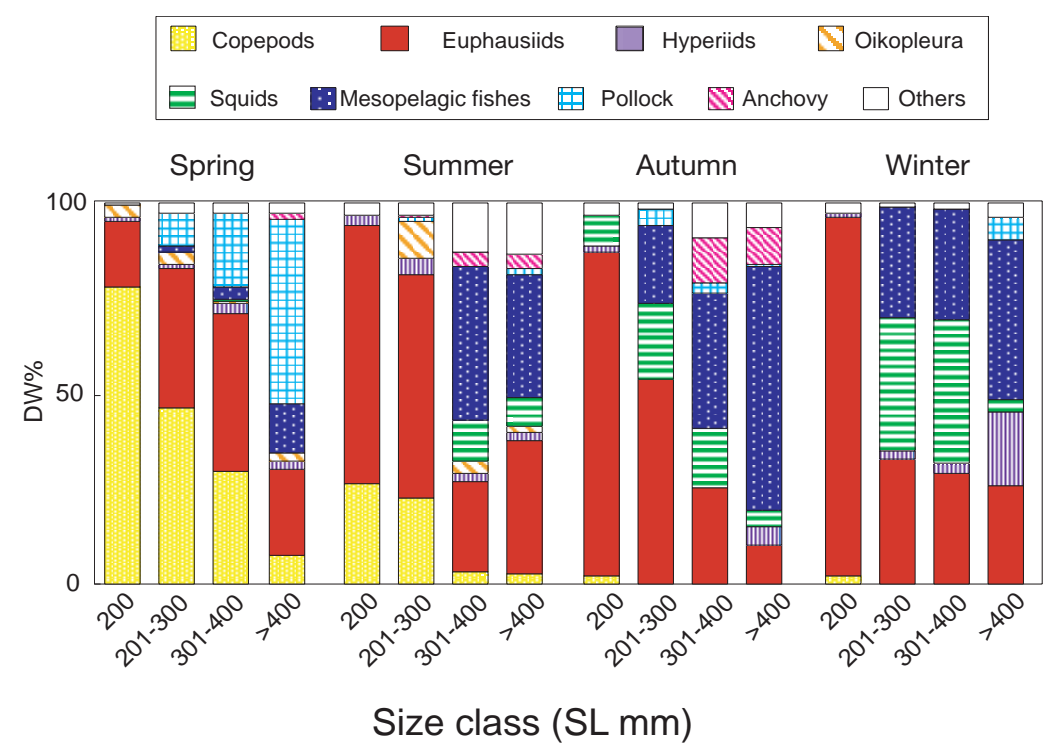

Fig. 2. Theragra chalcogramma. Dry weight prey composition by fish size and season based on samples collected during 1989 to 2000 in the Doto area. Season is defined as: spring, April to June; summer, July to September, etc.

\section{Comparison of diet by depth and fishing gear}

Pollock showed broadly similar seasonal and ontogenetic patterns of diet in the shallow and deep strata (Fig. 3). However, the occurrences of some prey taxa differed clearly by depth. During spring, copepods showed similar ontogenetic patterns in both strata. Cannibalism was more important in the shallow area, whereas euphausiids were more important in the deep area. During summer, no sufficient fish specimens $>200 \mathrm{~mm}$ were available in the shallow area due to offshore distribution reflecting seasonally raised water temperature. Therefore, the comparison was possible only for pollock $\leq 200 \mathrm{~mm}$, which mainly consisted of newly recruited age-0 fish. In both strata, pollock $\leq 200 \mathrm{~mm}$ showed similar diets which consisted mainly of euphausiids and copepods, but the proportion of copepods was higher in the deep stratum $(35.1 \%)$ than in the shallow $(15.1 \%)$.

\section{Seasonal variation of diet}

Pollock showed substantially different diets both by season and fish size (Fig. 2). During spring, copepods (mainly Neocalanus cristatus) were predominant for smaller pollock, and replaced gradually by euphausiids as fish grew. Walleye pollock (cannibalism) was the most important prey (48.1\%) for pollock $>400 \mathrm{~mm}$. During summer, the euphausiids increased their importance as part of the copepods in the diet for pollock $\leq 300 \mathrm{~mm}$. Oikopleura was a characteristic summer prey contributing $9.7 \%$ of diet in 201 to $300 \mathrm{~mm}$ pollock. Although Oikopleura from stomachs were unidentifiable due to advanced digestive stages, $O$. labradoriensis appeared to be present, which is abundant in the Oyashio waters (N. Shiga, Hokkaido University, pers. comm.). For larger pollock (>300 mm), mesopelagic fish and squids were important. Although the greatest portion of the overall diet was represented by northern species, southern species such as anchovy and saury also occurred during summer and autumn. In autumn, copepods were almost replaced by euphausiids. Squids became more common prey in larger size classes, whereas mesopelagic fish were predominant in pollock $>300 \mathrm{~mm}$. During winter, euphausiids were still an exclusively predominant prey for pollock $\leq 200 \mathrm{~mm}$; whereas mesopelagic fish and squids were also important in pollock of 201 to $400 \mathrm{~mm}$ size classes. Euphausiids and mesopelagic fish were predominant prey for pollock $>400 \mathrm{~mm}$.
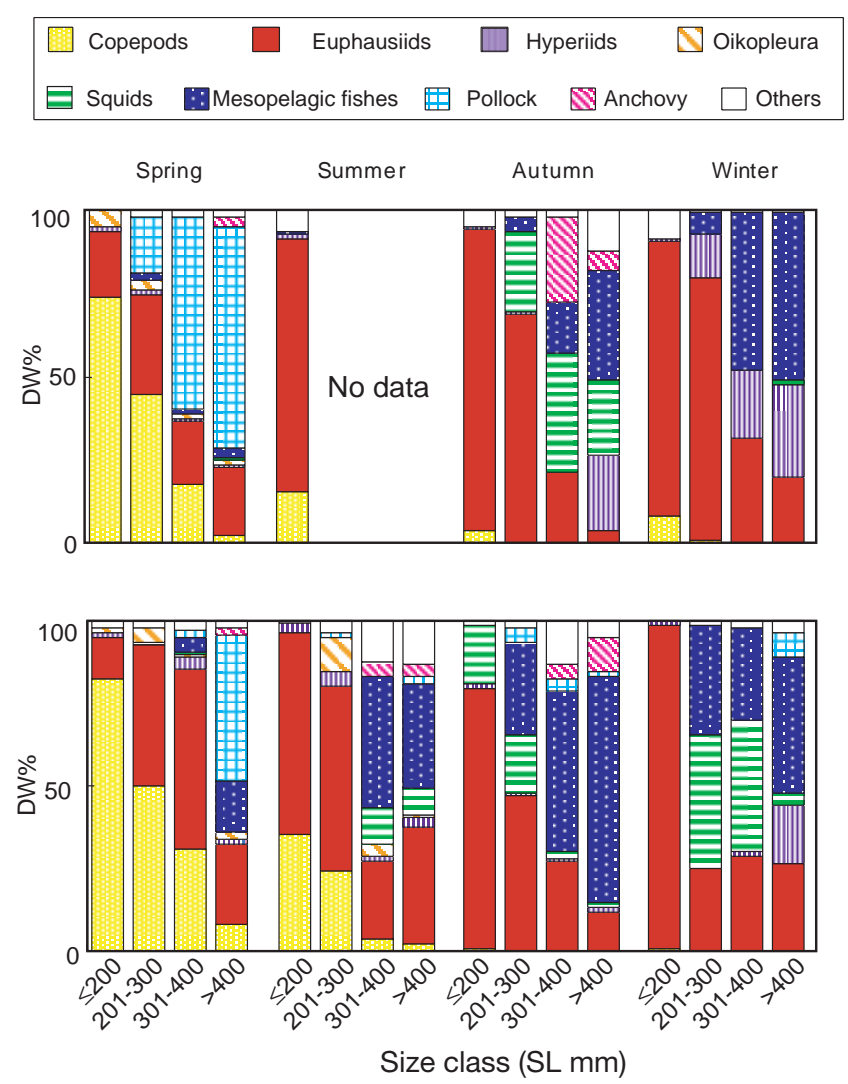

Fig. 3. Theragra chalcogramma. Diets for different fish size and season in shallow ( $\leq 150 \mathrm{~m}_{\text {; }}$ top) and deep (>150 $\mathrm{m}_{\text {; bot- }}$ tom) waters represented as dry weight percentage composition. Subsamples with $\geq 30$ fish specimens were included. Depths refer to maximum bottom depth at sampling 


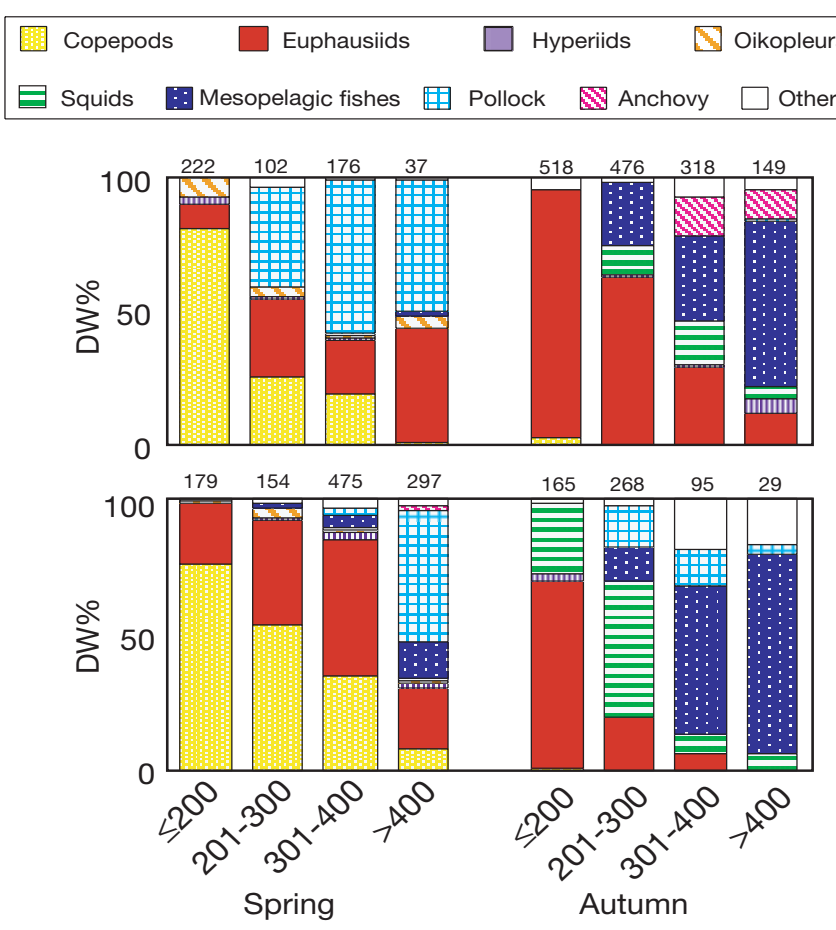

Fig. 4. Theragra chalcogramma. Diets for fish caught by different fishing gears: midwater trawl (top) and bottom trawl and gill net (bottom)

From autumn through winter, remarkable differences by depth were found in the predominance of micronekton and hyperiids. During autumn, squids were more important than mesopelagic fish whereas the opposite was true in the deep stratum. However, squids were found only in the deep area during winter. Hyperiids were more important in the shallow area during autumn and winter.

For the comparison between fishing gears (Fig. 4), sufficient specimens were available from spring and autumn. During spring, cannibalism occurred more commonly in the midwater whereas copepods and euphausiids were less important. However, cannibalism during autumn occurred only in the bottom layer. Squids were also more important in the bottom layer, while euphausiids were less important. Anchovy was found only in the midwater samples.

\section{Feeding intensity and condition}

In general, the SCI for pollock $>200 \mathrm{~mm}$ showed minima during winter and increased during spring, and then decreased gradually during summer and autumn (Fig. 5). However, 201 to $400 \mathrm{~mm}$ pollock showed incidental maxima during January. These high values were due to intense feeding on micronekton;

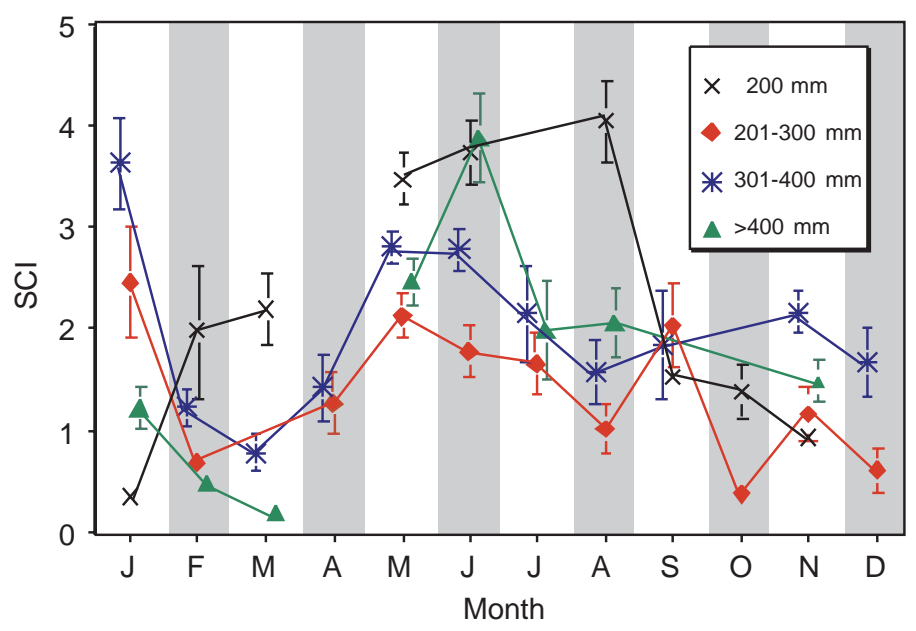

Fig. 5. Theragra chalcogramma. Monthly variation of mean $( \pm 1 \mathrm{SD})$ stomach contents index (SCI) for different size classes (SL, mm) in the Doto area. Subsamples represent $\geq 30$ fish

squids and mesopelagic fishes accounted for 41.9 and $29.9 \%$ in 201 to $300 \mathrm{~mm}$ pollock, and 51.7 and $32.6 \%$ in 301 to $400 \mathrm{~mm}$ pollock, respectively. The smallest size class of pollock showed somewhat different seasonal cycle of SCI compared with larger size classes. In the case of the smallest size pollock, there was a minimum during January which then increased through August and decreased abruptly during September and continued to decrease through January. The seasonal cycles of CF were similar between fish size classes (Fig. 6). In both size classes, CF was minimal during spring (April and May) and then increased abruptly through June $(\leq 400 \mathrm{~mm})$ or July $(>400 \mathrm{~mm})$. Whereas pollock $\leq 400 \mathrm{~mm}$ showed a continuous decrease from August through April, CF in pollock $>400 \mathrm{~mm}$ continued to increase from August through December.

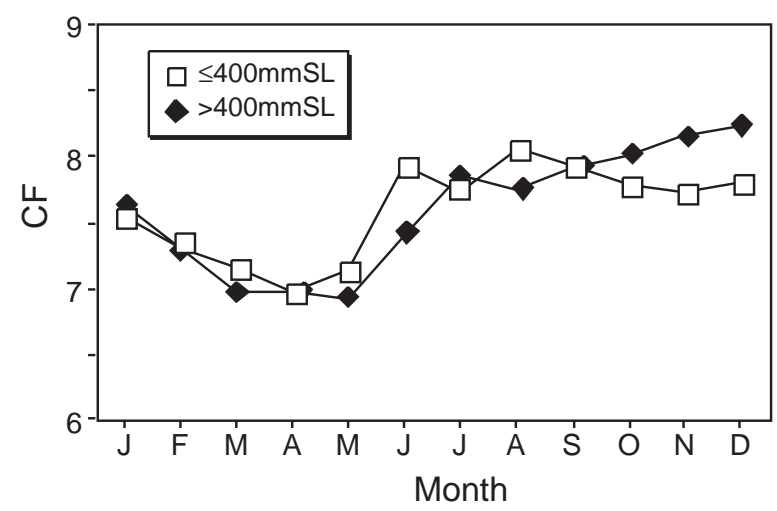

Fig. 6. Theragra chalcogramma. Monthly variation of mean condition factor (CF) for different size classes of fish in the Doto area based on ca 25000 market specimens collected during 1984 to 1997 . For definition of $\mathrm{CF}$, see text 


\section{DISCUSSION}

\section{Potential sources of error}

In the present study, feeding periodicity was not examined since the greatest portion of the specimens was sampled during daytime. The prey of pollock are generally diurnal vertical migrants along with pollock itself (e.g. Bailey 1989, Taki et al. 1996, Watanabe et al. 1999); therefore, pollock diet and feeding condition would vary by time of day. However, the relatively slow gastric evacuation rate of pollock (Dwyer et al. 1987, Yoshida 1994) and the low percentage of unidentifiable stomach contents found in the present study suggest a minimal bias due to daytime sampling. Variation of diet by sampling location has been found by previous authors (Dwyer et al. 1987, Mito et al. 1999) and was attributed to local differences in prey availability. Although fish specimens were sampled from a relatively narrow geographic range in the present study, local variation of prey distribution was probable in some occasions. For instance, warm core eddies shed by the Kuroshio extension can occasionally persist for months in the Doto area (Uehara et al. 1997). Such eddies create a distinct thermal and prey environment (e.g. Hattori 1993), and result in different diets and feeding performances of pollock. Furthermore, the shelf canyon situated off Kushiro (Fig. 1) seems to have a substantial influence on the physical and biological environments (Greene et al. 1988, Allen et al. 2001). To take these variations into consideration, samplings of finer spatial and temporal scales are required. Fish diet also varies interannually due to the variations in abundance and distribution of both predator and prey, as has been reported in other areas (Brodeur \& Pearcy 1992, Tanasichuk 1999). Therefore, the feeding habits presented here are given as an average over a decade, rather than a snapshot for a specific period.

\section{Food habits and their seasonal variation}

Pollock diet showed extensive variabilities both by fish size and season, reflecting changes in prey catchability as well as co-occurrence of predator and prey (Eggers 1982, Persson et al. 1996, Scharf et al. 2000). Further, it suggests that walleye pollock is an opportunistic feeder as has been shown for other gadids (e.g. Hop et al. 1993, Yamamura et al. 1993). Pollock depended (almost) exclusively ( $>99 \%$ ) on pelagic prey, which agrees well with its protruded lower jaw. However, ingestions of fair amounts of benthic animals by pollock have been reported from the eastern Bering Sea (EBS) (Dwyer et al. 1987, Mito et al. 1999). Given the opportunistic nature of pollock feeding, the difference would be due to prey abundance. The seasonal and ontogenetic pattern found in the Doto area resemble those found in the EBS; copepods were the most important prey for smaller pollock during spring and summer (Dwyer et al. 1987, Mito et al. 1999). Although no species identification was available in their studies, Yoshida (1994) pointed out that the copepods ingested by pollock in the central Bering Sea were dominated by Neocalanus cristatus (Calanus in his text) and $N$. plumchrus. However, Grover (1991) reported that the summer diet of age-1 pollock (131 to $220 \mathrm{~mm} \mathrm{TL}$ ) in the EBS was represented exclusively by Calanus marshallae and euphausiid furcilia and juveniles. Similarly, species composition of euphausiids in pollock diet also seems distinct in the EBS when compared to the Doto area; for example, whereas Euphausia pacifica was important in the Doto area, Thysanoessa spp. was predominant in the Bering Sea, reflecting the geographical difference in species composition of euphausiids (Coyle et al. 1992, O. Yamamura unpubl. data). The most notable difference between these areas was the occurrence of cannibalism. Although age- 0 pollock were cannibalized heavily during autumn and winter in the EBS, they represented only slight fractions in the diet of adult pollock in the Doto area. Instead, age-1 pollock were consumed during spring. The different seasonality and the age composition of the prey are due to the homogeneous thermal structure of the water column in the Doto area during spring (Yamamura et al. 2001). The water column is well stratified from summer through winter, providing thermal refuges for juveniles. However, the weak stratification during spring increases encounters with adults resulting in an increased incidence of cannibalism. In the Doto area, the occurrence of cannibalism was found to be density dependent; age-1 pollock were cannibalized more heavily in the year following strong recruitment. Yamamura et al. (2001) hypothesized that the 'overflow' of age-1 fish from the shelf waters during periods of high abundance would result in increased cooccurrence with adult fish and consequent cannibalism.

Spring diet differed distinctively from the other seasons with Neocalanus cristatus and cannibalism being predominant. The importance of copepods in the spring diet of pollock has been reported widely in previous studies (Bailey \& Dunn 1979, Dwyer et al. 1987, Mito et al. 1999, Willette et al. 1999). The occurrence of copepods in pollock diet synchronized well with the annual life cycle of $N$. cristatus in the Doto area. From April to July, when chlorophyll concentration is high, $N$. cristatus is distributed between the thermocline (20 to $80 \mathrm{~m}$ ) and $250 \mathrm{~m}$ depth, developing from copepodite stage 1 (C1) to C5. Then they migrate into deep layers where they diapause during summer (Kobari \& Ikeda 
1999). This vertical distribution overlaps with that of pollock during spring (S. Honda unpubl. data) and results in its importance in the pollock diet. Other predominant copepods in the Doto area, Neocalanus plumchrus/flemingeri and Eucalanus bungii, showed only slight occurrences from pollock stomach analyses. They partition habitat with each other, with $N$. plumchrus/flemingeri in the mixed layer and $E$. bungii below the thermocline (Mackas et al. 1993, Tsuda \& Sugisaki 1995). Accordingly, the small contribution of $N$. plumchrus/flemingeri in pollock diet was ascribable to the limited vertical overlap. As for E. bungii, its extremely transparent body likely avoided predation as has been reported for other copepods, in spite of the high degree of vertical overlap with pollock (Hays et al. 1994, Tsuda et al. 1998).

Euphausiids were an important prey item for pollock throughout. In the Doto area, euphausiids showed the highest abundance of $30 \mathrm{~g}$ wet wt $\mathrm{m}^{-2}$ (WWT) during June and then decreased gradually to $2 \mathrm{~g}$ WWT during February (O. Yamamura unpubl. data). However, the predominance of euphausiids was lowest in pollock diet during spring. This inconsistency was perhaps due to the superabundance of Neocalanus cristatus during spring, which exceeded $50 \mathrm{~g}$ WWT (A. Tsuda pers. comm.). From summer through winter, euphausiids remained to be the most predominant prey for pollock $\leq 200 \mathrm{~mm}$ although decreased abundance has been observed during this period. Two factors are probable for the steady dependence of pollock $\leq 200 \mathrm{~mm}$ upon euphausiids: (1) they cannot shift to micronekton as larger pollock did, due to size constraints; and (2) higher abundance or denser patches of euphausiids were encountered by pollock $\leq 200 \mathrm{~mm}$ inhabiting specific environments. Although detailed distribution of euphausiids during winter has been unavailable, $\leq 200 \mathrm{~mm}$ pollock attained moderate prey ingestion (SCI >2.0) during February and March although they showed a near-0 value during January (Fig. 5). These results suggest that juvenile pollock were distributed in a different environment compared with older fish. Further studies on winter distribution of pollock and euphausiids are needed since these prey seem crucial for winter survival of juveniles.

The southern epipelagic fishes (i.e. anchovy and saury) were ingested mainly during summer and autumn as a result of their northward migration into the subarctic area (Novikov 1986, Pearcy et al. 1996, Mihara 2000). Although pollock and anchovy co-occur because anchovy is often found at depths as deep as $150 \mathrm{~m}$ (S. Honda unpubl. data), natural encounters with saury were improbable as saury is distributed above the thermocline (Wada \& Kitakata 1982). Yamamura (1997) found saury in stomachs of demersal fishes including pollock off Sendai Bay. He concluded that the saury was not preyed upon, but was discarded by stick-held dip net fleets and was then scavenged by the fishes. This fishery also operates in the Doto area during summer and autumn. It is therefore suggested that the saury were discarded by the fleets, then scavenged by pollock. Micronekton, represented mainly by firefly squid and myctophids, was important for larger pollock except during spring, when cannibalism was important instead. This result suggests low availability of micronekton during spring along with a lack of thermal refuge for conspecific prey. However, we cannot draw a conclusion since quantitative data on seasonal abundance of micronekton in the Doto area is still wanting.

\section{Comparison by depth and fishing gear}

The importance of copepods and euphausiids showed differences by depth and fishing gear, with higher contribution in the shallow area and midwater. The differences were more obvious in larger pollock, whereas smaller individuals showed relatively steady diets over different depths and layers. Therefore, the differences were probably not due to different availability of mesozooplankton between depths and layers, but due to an ontogenetic difference in catchability of alternative prey. However, hyperiids represented mainly by Themisto spp. occurred more frequently in the shallow stratum. This seems to reflect the relation of Themisto spp. to the Kuroshio extension water, since the water mixes the upper layer of the Doto area from summer through winter (Kono 1997). The incidence of cannibalism was more frequent in the shallow area and in the midwater during spring. These results reflect the preference of age-1 pollock for shallow stratum (Watanabe et al. 1993). After comparing body sizes of cannibals and their prey by depths, Yamamura et al. (2001) suggested that deep-water adult pollock venture into shallow waters to cannibalize on juveniles. The present result suggests that the vertical overlap between cannibals and prey is also an important condition for the incidence of cannibalism. During autumn, cannibalism occurred only in the bottom layer of the deep area. Although we have no plausible explanation, the fact that greater numbers of potential prey $<200 \mathrm{~mm}$ have been sampled in the midwater (see Fig. 4) suggests that the present result was not derived from prey pollock distribution but from some other factor(s).

Squids, represented mainly by firefly squid, occurred in both of the shallow and deep strata during autumn, but only in the deep stratum during winter. This implies cross-shore movement of firefly squid in relation to physical environment and/or reproduction 
(Yamamura \& Inada 2001). The importance of mesopelagic fish was generally higher in the deep stratum, with an exception for pollock $>300 \mathrm{~mm}$ during winter. The occurrence of mesopelagic fish from the shallow area was curious since deep scattering layers representing aggregations of micronekton have been observed only in the areas with $>150 \mathrm{~m}$ bottom depths (S. Honda unpubl. data). Plausible explanations for the occurrence in the shallow area are: (1) mesopelagic fish were advected to the shallow area as they ascended during nighttime (Perissinotto \& McQuaid 1992); and (2) pollock containing mesopelagic fish in their stomachs were sampled after moving into the shallow area from the deep area. Detailed data on distribution of mesopelagic fishes is needed to draw a conclusion.

\section{Implications for the seasonal cycle}

The condition of pollock decreased steadily during winter, although moderate to high SCI values were observed (Figs. 4 \& 5). Since the maturation of pollock generally occurs as they grow $>400 \mathrm{~mm}$ SL (Hamatsu et al. 1993), the decrease of SCI in pollock $\leq 400 \mathrm{~mm}$ represents the expenditure of energy reserves under reduced food availability, whereas the transformation of energy to gonad maturation was probable for fish $>400 \mathrm{~mm}$. Decrease of condition during winter has been frequently reported in high latitude fishes (e.g. Griffiths \& Kirkwood 1995, Paul \& Paul 1998) and it has a potential to cause size-selective mortality in juveniles (Sogard 1997). The SCI of pollock $>400 \mathrm{~mm}$ continued to decrease during winter, reaching almost 0 during March. This decrease was partly due to compression of the abdominal cavity as a result of maturation since the spawning of walleye pollock occurs during early spring (Maeda 1986, Hamatsu \& Yabuki 1995). On the contrary, fish $\leq 200 \mathrm{~mm}$ showed relatively high values of SCI during February and March. Since smaller fish exhaust stored energy more quickly than larger fish, due to both fewer reserves and a higher metabolic rate (Paul 1986), smaller fish need to ingest food more frequently than larger fish. In a laboratory experiment, $>80 \%$ of overwintering juvenile pollock endured starvation for $>200 \mathrm{~d}$ at a temperature of $0.5^{\circ} \mathrm{C}$ (Sogard \& Olla 2000). However, water temperature during winter tends to be higher $\left(\sim 3^{\circ} \mathrm{C}\right)$ in the Doto area (Kono \& Kawasaki 1997, Saito et al. 1998). Juveniles therefore need to feed continuously to support their metabolic demand (Paul et al. 1998), using Euphausia pacifica during February and March. Given the necessity of feeding during winter, the availability of E. pacifica seems critical for winter survival of juvenile pollock.
Pollock showed a rapid recovery of feeding condition during May. Since juveniles fed mainly on Neocalanus cristatus and adults cannibalized on juveniles, both juveniles and adults recovered utilizing $N$. cristatus directly and indirectly, respectively. It is therefore considered that $N$. cristatus plays an important role in transmitting primary production immediately to recovering pollock. Variations in the duration of Neocalanus 'bloom' associated with the degree of stratification of the surface caused dietary shifts in pollock in Prince Williams Sound (Willette et al. 1999). In addition, in the Oyashio area, spring bloom is determined by the vertical stability of the water column (Yoshimori et al. 1995) and is subjected to temporal variability (Kasai et al. 1997). It is therefore suggested that climatic variability has a potential to delay the timing of $N$. cristatus 'bloom' as has been reported in the NE Pacific (Mackas et al. 1998) and would therefore seriously affect the survival of wintering juvenile pollock by extending the starvation period.

Acknowledgements. Our sincerest gratitude goes to M. Ishiguro for her dedicated assistance in the laboratory. We would like to thank T. Ikeda, P. Livingston, M. Moku, N. Shiga and A. Tsuda for helpful discussions. We also wish to thank M. Chiba, K. Fujita, T. Hattori, T. Komai, K. Kooka, Y. Matsushita, S. Ohshimo, K. Uchikawa, K. Watanabe, K. Yabuki and $\mathrm{T}$. Yanagimoto for their help in sample collection; officers and crews of FRVs 'Hokuhou-Maru', 'Hokushin-Maru', 'KaiyoMaru', 'Kaiyo-Maru 3', 'Seitoku-Maru 2', 'Tanshu-Maru', 'Torishima', 'Wakataka-Maru' and 'Yohkoh-Maru' for their assistance at sea; C. Arakawa, K. Hara, Y. Hareyama, H. Saito and S. Ueda for their laboratory assistance. This study was supported by grants from the Ministry of Agriculture, Forestry and Fisheries, Japan.

\section{LITERATURE CITED}

Adams SM, McLean RB, Huffman MM (1982) Structuring of a predator population through temperature-mediated effects on prey availability. Can J Fish Aquat Sci 39:1175-1184

Allen SE, Vinderirinho C, Thomson RE, Foreman MGG, Mackas DL (2001) Physical and biological processes over a submarine canyon during an upwelling event. Can J Fish Aquat Sci 58:671-684

Anonymous (2000) FAO yearbook. Fishery statistics: Commodities. 1998. FAO, Rome

Bailey KM (1989) Interaction between the vertical distribution of juvenile walleye pollock Theragra chalcogramma in the eastern Bering Sea, and cannibalism. Mar Ecol Prog Ser 53:205-213

Bailey K, Dunn J (1979) Spring and summer foods of walleye pollock, Theragra chalcogramma, in the eastern Bering Sea. Fish Bull 77:304-308

Bailey KM, Powers DM, Quattro JM, Villa G, Nishimura A, Traynor JJ, Walters G (1999) Population ecology and structual dynamics of walleye pollock (Theragra chalcogramma). In: Loughlin TR, Ohtani K (eds) Dynamics of the Bering Sea. University of Alaska Sea Grant, Fairbanks, AK, p 581-614

Brodeur RD (1998) Prey selection by age-0 walleye pollock, 
Theragra chalcogramma, in nearshore waters of the Gulf of Alaska. Environ Biol Fish 51:175-186

Brodeur RD, Pearcy WG (1992) Effects of environmental variability on trophic interactions and food web structure in a pelagic upwelling ecosystem. Mar Ecol Prog Ser 84: 101-119

Clausen DM (1983) Food of walleye pollock, Theragra chalcogramma, in an embayment of southeastern Alaska. Fish Bull 81:637-642

Coyle KO, Hunt GL Jr, Decker MB, Weingartner TJ (1992) Murre foraging, epibenthic sound scattering and tidal advection over a shoal near St. George Island, Bering Sea. Mar Ecol Prog Ser 83:1-14

Dwyer DA, Bailey KM, Livingston PA (1987) Feeding habits and daily ration of walleye pollock (Theragra chalcogramma) in the eastern Bering Sea, with special reference to cannibalism. Can J Fish Aquat Sci 44:1972-1984

Dygert PH (1990) Seasonal changes in energy content and proximate composition associated with somatic growth and reproduction in a representative age-class of female English sole. Trans Am Fish Soc 119:791-801

Eggers DM (1982) Planktivore preference by prey size. Ecology 63:381-390

Eggold BT, Motta PJ (1992) Ontogenetic dietary shifts and morphological correlates in striped mullet, Mugil cephalus. Environ Biol Fish 34:139-158

Greene CH, Wiebe PH, Burczynski J, Youngbluth MJ (1988) Acoustical detection of high-density demersal krill layers in the submarine canyons off Georges Bank. Science 241: 359-361

Griffiths D, Kirkwood RC (1995) Seasonal variation in growth, mortality and fat stores of roach and perch in Lough Neagh, Northern Ireland. J Fish Biol 47:537-554

Grover JJ (1991) Trophic relationship of age-0 and age-1 walleye pollock Theragra chalcogramma collected together in the eastern Bering Sea. Fish Bull 88:719-722

Hamatsu T, Yabuki K (1995) Spawning migration and spawning ground of walleye pollock Theragra chalcogramma distributed along the Pacific coast of eastern Hokkaido. Bull Hokkaido Natl Fish Res Inst 59:31-41

Hamatsu T, Yabuki K, Watanabe K (1993) Maturity and fecundity of walleye pollock Theragra chalcogramma in the Pacific coast of southeastern Hokkaido. Bull Hokkaido Natl Fish Res Inst 57:43-51

Harris RK, Nishiyama T, Paul AJ (1986) Carbon, nitrogen and caloric content of eggs, larvae, and juveniles of the walleye pollock, Theragra chalcogramma. J Fish Biol 29: $87-98$

Hattori H (1993) Vertical distribution of zooplankton in the warm core off Sanriku (86B) and adjacent Oyashio water, with special reference to copepods record. Bull Hokkaido Natl Fish Res Inst 55:59-77

Hays GC, Proctor CA, John AW, Warner AJ (1994) Interspecific differences in the diel vertical migration of marine copepods: The implications of size, color, and morphology. Limnol Oceanogr 39:1621-1629

Henderson PA, Holmes RH, Bamber RN (1988) Size-selective overwintering mortality in the sand smelt, Atherina boyeri Risso, and its role in population regulation. J Fish Biol 33: 221-233

Hop H, Danielssen DS, Gjøseter J (1993) Winter feeding ecology of cod (Gadus morhua) in a fjord of southern Norway. J Fish Biol 43:1-18

Hyndes GA, Platell ME, Potter IC (1997) Relationships between diet and body size, mouth morphology, habitat and movements of six sillaginid species in coastal waters: Implications for resource partitioning. Mar Biol 128: 585-598
Kasai H, Saito H, Yoshimori A, Taguchi S (1997) Variability in timing and magnitude of spring bloom in the Oyashio region, the western subarctic Pacific off Hokkaido, Japan. Fish Oceanogr 6:118-129

Kitagawa D, Ishito T, Okuyama Y, Sakurai Y, Inada T (1992) Preys discarded by the Japanese common squid, Todarodes pacificus, occurring in the stomachs of brown hakeling, Physiculus maximowiczi. Bull Tohoku Natl Fish Res Inst 54:59-66

Kobari T, Ikeda T (1999) Vertical distribution, population structure and life cycle of Neocalanus crustatus (Crustacea: Copepoda) in the Oyashio region, with notes on its regional variations. Mar Biol 134:683-696

Kono T (1997) Modification of the Oyashio Water in the Hokkaido and Tohoku areas. Deep-Sea Res 44:669-688

Kono T, Kawasaki Y (1997) Results of CTD and mooring observations southeast of Hokkaido. 1. Annual variations of water mass structure and salt flux of the Oyashio. Bull Hokkaido Natl Fish Res Inst 61:83-95

Kooka K, Takatsu T, Kamei Y, Nakatani T, Takahashi T (1997) Food habits of walleye pollock inhabiting the mesopelagic zone in the nothern Japan Sea in spring and autumn. Nippon Suisan Gakkaishi 63:537-541

Livingston PA (1993) Importance of predation by groundfish, marine mammals and birds on walleye pollock Theragra chalcogramma and Pacific herring Clupea pallasi in the eastern Bering Sea. Mar Ecol Prog Ser 102:205-215

Mackas DL, Tsuda A (1999) Mesozooplankton in the eastern and western subarctic Pacific: community structure, seasonal life histories, and interannual variability. Prog Oceanogr 43:335-363

Mackas DL, Sefton H, Miller CB, Raich A (1993) Vertical habitat partitioning by large calanoid copepods in the oceanic Subarctic Pacific during spring. Prog Oceanogr 32: 259-294

Mackas DL, Goldblatt R, Lewis AG (1998) Interdecadal variation in developmental timing of Neocalanus plumchrus populations at Ocean Station P in the subarctic North Pacific. Can J Fish Aquat Sci 55:1878-1893

MacKinnon JC (1972) Summer storage of energy and its use for winter metabolism and gonad maturation in American plaice (Hippoglossoides platessoides). J Fish Res Board Can 29:1749-1759

Maeda T (1986) Life cycle and behavior of adult pollock (Theragra chalcogramma [Pallas]) in water adjacent to Funka Bay, Hokkaido Island. Bull Int North Pac Fish Comm 45:39-65

Marshall CT, Yaragina NA, Lambert Y, Kjesbu OS (1999) Total lipid energy as a proxy for total egg production by fish stocks. Nature 402:288-290

Merati N, Brodeur RD (1996) Feeding habits and daily ration of juvenile walleye pollock, Theragra chalcogramma, in the western Gulf of Alaska. In: Brodeur RD, Livingston $\mathrm{P}_{\text {, }}$ Loughlin TR, Hollowed AB (eds) Ecology of juvenile walleye pollock, NOAA Tech Rep 126. US Department of Commerce, Seattle, p 65-79

Mihara Y (2000) Maturation of the Japanese anchovy, Engraulis japonicus, off southeastern Hokkaido and adjacent waters. Bull Jpn Soc Fish Oceanogr 64:10-17

Mito K, Nishimura A, Yanagimoto T (1999) Ecology of groundfishes in the eastern Bering Sea, with emphasis on food habits. In: Loughlin TR, Ohtani K (eds) Dynamics of the Bering Sea. University of Alaska Sea Grant, Fairbanks, AK, p 537-580

Miyake H, Yoshida H, Ueda Y (1996) Distribution and abundance of age-0 juvenile walleye pollock, Theragra chalcogramma, along the Pacific coast of southeastern Hokkaido, Japan. NOAA Tech Rep NMFS 126:3-10 
Novikov YV (1986) Some trends of distribution and migration of common pelagic fishes of the northwestern Pacific Ocean. J Ichthyol 26:161-172

Paul AJ (1986) Respiration of juvenile pollock, Theragra chalcogramma (Pallas), relative to body size and temperature. J Exp Mar Biol Ecol 97:287-293

Paul AJ, Paul JM (1998) Comparisons of whole body energy content of captive fasting age zero Alaskan Pacific herring (Clupea pallasi Valenciennes) and cohorts over-wintering in nature. J Exp Mar Biol Ecol 226:75-86

Paul AJ, Paul JM, Smith RL (1998) Seasonal changes in whole-body energy content and estimated consumption rates of age 0 walleye pollock from Prince William Sound, Alaska. Estuar Coast Shelf Sci 47:251-259

Pearcy WG, Fisher JP, Anma G, Megura T (1996) Species associations of epipelagic nekton of the North Pacific Ocean, 1978-1993. Fish Oceanogr 5:1-20

Perissinotto R, McQuaid CD (1992) Land-based predator impact on vertically migrating zooplankton and micronekton advected to a Southern Ocean archipelago. Mar Ecol Prog Ser 80:15-27

Persson L, Andersson J, Wahlstrom E, Eklov P (1996) Sizespecific interactions in lake systems: predator gapelimitation and prey growth rate and mortality. Ecology 77 : 900-911

Robards MD, Anthony JA, Rose GA, Piatt JF (1999) Changes in proximate composition and somatic energy content for Pacific sand lance (Ammodytes hexapterus) from Kachemak Bay, Alaska, relative to maturity and season. J Exp Mar Biol Ecol 242:245-258

Saito H, Kasai H, Kashiwai M, Kawasaki Y, Kono T, Taguch S, Tsuda A (1998) General description of seasonal variations in nutrients, chlorophyll $a$, and netplankton biomass along the A-line transect, western subarctic Pacific, from 1990 to 1994. Bull Hokkaido Natl Fish Res Inst 62:1-62

Scharf FS, Juanes F, Rountree RA (2000) Predator size - prey size relationships of marine fish predators: interspecific variation and effects of ontogeny and body size on trophicniche breadth. Mar Ecol Prog Ser 208:229-248

Smith RL, Paul AJ, Paul JM (1988) Aspects of energetics of adult walleye pollock, Theragra chalcogramma (Pallas), from Alaska. J Fish Biol 33:445-454

Sogard SM (1997) Size-selective mortality in the juvenile stage of teleost fishes: a review. Bull Mar Sci 60: 1129-1157

Sogard SM, Olla BL (2000) Endurance of simulated winter conditions by age-0 walleye pollock: effects of body size, winter temperature and energy stores. J Fish Biol 56:1-21

Springer AM (1992) A review: walleye pollock in the North Pacific-how much difference do they really make? Fish Oceanogr 1:80-96

Takahashi Y, Yamaguchi H (1972) Stock of the Alaska pollock in the eastern Bering Sea. Bull Jpn Soc Sci Fish 38: 389-399

Editorial responsibility: Otto Kinne (Editor), Oldendorf/Luhe, Germany
Taki K, Kotani Y, Endo Y (1996) Ecological studies of Euphausia pacifica Hansen and seasonal change of its environment off Onagawa, Miyagi Prefecture. III. Distribution and diel vertical migration of Euphausia pacifica. Bull Tohoku Natl Fish Res Inst 58:89-104

Tanasichuk RW (1999) Interannual variation in the availability and utilization of euphausiids as prey for Pacific Hake (Merluccius productus) along the south-west coast of Vancouver Island. Fish Oceanogr 8:150-156

Tsuda A, Sugisaki H (1995) In situ grazing rate of the copepod population in the western subarctic North Pacific during spring. Mar Biol 120:203-210

Tsuda A, Saito H, Hirose T (1998) Effect of gut content on the vulnerability of copepods to visual predation. Limnol Oceanogr 43:1944-1947

Uehara K, Miyake H, Okazaki M (1997) Characteristics of the flows in the Oyashio area off Cape Erimo, Hokkaido, Japan. J Oceanogr 53:93-103

Wada T, Kitakata M (1982) Sampling research with mid-water drift gillnet and behaviour of saury in the daytime. Bull Hokkaido Fish Res Inst 47:11-22

Watanabe K, Yabuki K, Hamatsu T, Yamamura O (1993) Distribution of walleye pollock Theragra chalcogramma along the coast of southeastern Hokkaido, in the early summer. Bull Hokkaido Natl Fish Res Inst 57:53-61

Watanabe H, Moku M, Kawaguchi K, Ishimaru K, Ohno A (1999) Diel vertical migration of myctophid fishes (Family Myctophidae) in the transition waters of the western North Pacific. Fish Oceanogr 8:115-127

Willette TM, Cooney RT, Hyer K (1999) Predator foraging mode shifts affecting mortality of juvenile fishes during the subarctic spring bloom. Can J Fish Aquat Sci 56: $364-376$

Yamamura O (1997) Scavenging on discarded saury by demersal fishes off Sendai Bay, northern Japan. J Fish Biol 50:919-925

Yamamura O, Inada T (2001) Importance of micronekton as food of demersal fish assemblages. Bull Mar Sci 68:13-25

Yamamura O, Watanabe K, Shimazaki K (1993) Feeding habits of Pacific cod, Gadus macrocephalus, off eastern Hokkaido, north Japan. Proc NIPR Symp Polar Biol 6: $44-54$

Yamamura O, Yabuki K, Shida O, Watanabe K, Honda S (2001) Spring cannibalism on 1 year walleye pollock in the Doto area, northern Japan: is it density-dependent? J Fish Biol 59:645-656

Yoshida H (1994) Food and feeding habits of pelagic walleye pollock in the central Bering Sea in summer, 1976-1980. Sci Rep Hokkaido Fish Exp Stn 45:1-35

Yoshimori A, Ishizaka J, Kono T, Kasai H, Saito H, Kishi MJ, Taguchi S (1995) Modeling of spring bloom in the western subarctic Pacific (off Japan) with observed vertical density structure. J Oceanogr 51:471-488

Submitted: November 2, 2001; Accepted: April 2, 2002 Proofs received from author(s): July 15, 2002 